\title{
Show your beaks and we tell you what you eat: Different ecology in sympatric Antarctic benthic octopods under a climate change context
}

\author{
Ricardo S. Matias ${ }^{\mathrm{a}, *}$, Susan Gregory ${ }^{\mathrm{b}, \mathrm{c}}$, Filipe R. Ceia ${ }^{\mathrm{a}}$, Alexandra Baeta ${ }^{\mathrm{a}}$, José Seco ${ }^{\mathrm{d}, \mathrm{e}}$, \\ Miguel S. Rocha ${ }^{f, g}$, Emanuel M. Fernandes ${ }^{f, g}$, Rui L. Reis ${ }^{f, g, h}$, Tiago H. Silva ${ }^{\mathrm{f}, g}$, Eduarda Pereira ${ }^{\mathrm{d}}$, \\ Uwe Piatkowski ${ }^{i}$, Jaime A. Ramos ${ }^{\mathrm{a}}$, José C. Xavier ${ }^{\mathrm{a}, \mathrm{b}}$ \\ ${ }^{\mathrm{a}}$ Marine and Environmental Sciences Centre (MARE), Department of Life Sciences, Faculty of Sciences and Technology of the University of Coimbra, 3000-456, Coimbra, \\ Portugal \\ ${ }^{\mathrm{b}}$ British Antarctic Survey, Natural Environment Research Council, High Cross, Madingley Road, Cambridge, CB3 OET, United Kingdom \\ ${ }^{\mathrm{c}}$ Government of South Georgia and the South Sandwich Islands, Stanley, Falkland Islands \\ ${ }^{\mathrm{d}}$ Centre for Environmental and Marine Studies (CESAM), Department of Chemistry, University of Aveiro, Campus Universitário de Santiago, 3810-193, Aveiro, Portugal \\ ${ }^{\mathrm{e}}$ School of Biology, University of St Andrews KY16 9ST, Scotland, United Kingdom \\ ${ }^{\mathrm{f}} 3 B$ 's Research Group, I3Bs - Research Group on Biomaterials, Biodegradables and Biomimetics, University of Minho, Headquarters of the European Institute of Excellence \\ on Tissue Engineering and Regenerative Medicine, AvePark, Parque de Ciência e Tecnologia, Zona Industrial da Gandra, 4805-017, Barco, Guimarães, Portugal \\ ${ }^{g}$ ICVS/3B's - PT Government Associate Laboratory, Braga, Guimarães, Portugal \\ ${ }^{\mathrm{h}}$ The Discoveries Centre for Regenerative and Precision Medicine, Headquarters at University of Minho, Avepark, 4805-017, Barco, Guimarães, Portugal \\ ${ }^{\mathrm{i}}$ GEOMAR, Helmholtz Centre for Ocean Research Kiel, Düsternbrooker Weg 20, 24105, Kiel, Germany
}

\section{A R T I C L E I N F O}

\section{Keywords:}

Cephalopods

Sympatry

South Georgia

Stable isotopes

Mercury

Biomaterials

\begin{abstract}
A B S T R A C T
Sympatry can lead to higher competition under climate change and other environmental pressures, including in South Georgia, Antarctica, where the two most common octopod species, Adelieledone polymorpha and Pareledone turqueti, occur side by side. Since cephalopods are typically elusive animals, the ecology of both species is poorly known. As beaks of cephalopods are recurrently found in top predator's stomachs, we studied the feeding ecology of both octopods through the evaluation of niche overlapping and specific beak adaptations that both species present. A multidisciplinary approach combining carbon $\left(\delta^{13} \mathrm{C}\right)$ and nitrogen $\left(\delta^{15} \mathrm{~N}\right)$ stable isotope signatures, mercury $(\mathrm{Hg}$ ) analysis and biomaterials' engineering techniques was applied to investigate the beaks. An isotopic niche overlap of $95.6 \%$ was recorded for the juvenile stages of both octopod species, dropping to $19.2 \%$ for the adult stages. Both $A$. polymorpha and $P$. turqueti inhabit benthic ecosystems around South Georgia throughout their lifecycles $\left(\delta^{13} \mathrm{C}:-19.21 \pm 1.87 \%\right.$, mean \pm SD for both species) but explore trophic niches partially different during adult life stages $\left(\delta^{15} \mathrm{~N}: 7.01 \pm 0.40 \%\right.$, in A. polymorpha, and $7.84 \pm 0.65 \%$, in P. turqueti). The beaks of $A$. polymorpha are less dense and significantly less stiff than in $P$. turqueti. Beaks showed lower mercury concentration relative to muscle (A. polymorpha - beaks: $0.052 \pm 0.009 \mu \mathrm{gg}^{-1}$, muscle: $0.322 \pm 0.088 \mu \mathrm{g} \mathrm{g}^{-1}$; P. turqueti - beaks: $0.038 \pm 0.009 \mu \mathrm{g} \mathrm{g}^{-1}$; muscle: $0.434 \pm 0.128 \mu \mathrm{g} \mathrm{g}^{-1}$ ). Overall, both octopods exhibit similar habitats but different trophic niches, related to morphology/function of beaks. The high $\mathrm{Hg}$ concentrations in both octopods can have negative consequences on their top predators and may increase under the present climate change context.
\end{abstract}

\section{Introduction}

Sympatry in Antarctic cephalopods has started to be addressed, in the sense that close-related species with similar ontogenetic/phylogenetic life-history strategies may display different patterns of genetic differentiation (Strugnell et al., 2017). Two species are considered sympatric when sharing the same geographical region thus frequently encountering each other while exploiting the available natural resources. To avoid competition and probable extinction of the inferior competitor, ecological niche theory predicts sympatric species exploit differently the habitat allowing their coexistence (Hardin, 1960). Niche differentiation, documented in various organisms, such as birds, reptiles (MacArthur, 1958; Pacala and Roughgarden, 1985) and cephalopods (Bennice et al., 2019), can occur by using different habitats or

\footnotetext{
* Corresponding author.

E-mail address: ricardomatias.bio@gmail.com (R.S. Matias).
} 
consuming different prey. However, few studies have documented competition between sympatric cephalopods, particularly in polar regions, failing to describe interspecific relationships that might influence marine biota. A better understanding of cephalopods will allow to understand interspecific relationships in the Antarctic ecosystem, as cephalopods play important roles by constituting strong links between trophic levels (Collins and Rodhouse, 2006; Xavier et al., 2018). Climate change associated environmental factors are likely to influence the current structure and functioning of Antarctic ecosystems (Constable et al., 2014; Gutt et al., 2015; Rintoul et al., 2018), thus raising concern about the future of keystone cephalopod species.

The octopods Adelieledone polymorpha (Robson, 1930) and Pareledone turqueti (Joubin, 1905) are the two most abundant sympatric species of benthic Antarctic cephalopods (family: Megaleledonidae) living on the South Georgia shelf (Collins et al., 2004). They are the main prey for some top predators, such as pinnipeds and commercially valuable fish like the Patagonian Toothfish, Dissostichus eleginoides (Negri et al., 2016; Rodhouse et al., 1992; Xavier et al., 2002). Around South Georgia, A. polymorpha and P. turqueti have been found down to 15-862 and 25-640 m deep, respectively (Allcock, 1997). Even though both species can be found at similar depths, $P$. turqueti is more abundant at shallower depths relative to A. polymorpha (Yau et al., 2002). Since both species produce large-egg hatchlings and seem to show high parental investment (e.g. brooding), adult dispersal is limited (Barratt et al., 2008; Schwarz et al., 2018; Villanueva and Norman, 2008). Notwithstanding, the arms of A. polymorpha have higher number of suckers of smaller diameter and its body is more fragile (i.e. more prone to damage when caught on nets) than $P$. turqueti, which might indicate that both species exploit habitats differently (Daly and Rodhouse, 1994). Great dissimilarities can also be found in the digestive system of the two species: different sizes of posterior salivary gland (PSG) and buccal masses; different beak morphology (Xavier and Cherel, 2009). Whilst $P$. turqueti beaks present features common to other benthic octopods, the lower beak of $A$. polymorpha has an unique shape that clearly differs from all other octopods (Allcock et al., 2003; Daly and Rodhouse, 1994), indicating that both species occupy different trophic niches. Previous dietary studies have recorded a broadly similar diet composed by amphipods, polychaetes and other invertebrates on both species, but differing in the identification of the presence of few remains of hard-shelled prey, octopods and fishes in the diet of $P$. turqueti (Daly, 1996; Piatkowski et al., 2003). As these both species possess clearly different beaks, such characteristics may allow a better understanding of the trophic differences found in their diets.

Due to morphological and trophic specific traits in A. polymorpha and $P$. turqueti, our research aims to test for differences in habitat use and trophic ecology of these sympatric octopod species and assess their specific roles in the Antarctic marine ecosystem. It is hypothesized that both octopods occupy benthic habitats within the South Georgia coastal region while exploring trophic niches composed of different prey communities. The different methods of exploiting different sorts of prey are made possible by functional morphological adaptations that both species possess, such as the diverse characteristics of their beaks (Allcock et al., 2003; Daly and Rodhouse, 1994). As cephalopod diversity of South Georgia marine ecosystems and the pivotal role that these organisms have on marine food webs are still not entirely understood, filling existing gaps of knowledge is crucial to fully understand the benthic functional diversity and which ecological drivers dictate the community (Alvito et al., 2014; Collins et al., 2004; Xavier et al., 2003). Furthermore, the gathered knowledge will inform future conservation measures implemented through the recently established South Georgia and South Sandwich Islands Marine Protected Area (Hogg et al., 2016; Rogers et al., 2015; Trathan et al., 2014).

To accomplish this study, beaks of $A$. polymorpha and $P$. turqueti were analysed morphologically and their habitat and trophic levels investigated using a multidisciplinary approach:
(1) Applying novel biomaterial engineering techniques, including scanning electron microscopy (SEM), X-ray diffraction (XRD), highresolution microcomputed tomography $(\mu \mathrm{CT})$ and nanoindentation test $(\mathrm{NNI})$, provide detailed information on microstructure, composition and density of hard tissues (Cárdenas et al., 2004; Miserez et al., 2007). Since both species are closely related, we expected to find no differences in the beak's microstructure between them, with beak morphology being the key factor in determining physical properties, such as stiffness.

(2) Stable isotope analyses have been successfully applied to study the trophic signals in cephalopod beaks (Cherel and Hobson, 2005; Zimmer et al., 2007). Through stable isotope ratios of carbon $\left({ }^{13} \mathrm{C} /{ }^{12} \mathrm{C}, \delta^{13} \mathrm{C}\right)$ and nitrogen $\left({ }^{15} \mathrm{~N} /{ }^{14} \mathrm{~N}, \delta^{15} \mathrm{~N}\right)$ applied in different regions of the beaks, we studied ontogenetic shifts in species' habitat and trophic ecology. Values of $\delta^{13} \mathrm{C}$ were used to determine habitat (e.g. higher vs lower latitude, inshore vs offshore) and $\delta^{15} \mathrm{~N}$ values to trophic niche (Cherel and Hobson, 2007; Hobson and Welch, 1992). Since A. polymorpha and $P$. turqueti are benthic octopods, we believe that both inhabit coastal ecosystems on the South Georgia shelf throughout their lifecycle. Ontogenetic dietary shifts are expected in both species, although a broader range of $\delta^{15} \mathrm{~N}$ values is expected to be found in $P$. turqueti due to its more generalist feeding behavior (Daly, 1996; Piatkowski et al., 2003).

(3) Mercury has been successfully applied to trophic studies before, as its concentration is biomagnified along trophic levels (Atwell et al., 1998; Bargagli et al., 1998). We expect that $P$. turqueti feeds on prey of higher trophic levels thus presenting higher total mercury (T-Hg) concentrations in its tissues relative to A. polymorpha. As little is known about cephalopods' beaks mercury uptake, T-Hg concentrations on beaks will also be assessed and compared to T-Hg concentrations in the same individual's muscle. T-Hg concentrations on beaks are expected to be lower relative to muscle.

\section{Materials and methods}

Beaks of A. polymorpha $\left(\mathrm{n}_{\mathrm{Upper}}=40, \mathrm{n}_{\text {Lower }}=45\right)$ and $P$. turqueti $\left(\mathrm{n}_{\text {Upper }}=43, \mathrm{n}_{\text {Lower }}=46\right)$ were randomly selected from: whole individuals $\left(\mathrm{n}_{A \text {. polymorpha }}=30, \mathrm{n}_{P \text {. turqueti }}=31\right)$ captured at depths ranging from 100 to $400 \mathrm{~m}$, during 30 -min bottom trawling stations carried out along South Georgia coast, in 2004 (Fig. 1), by the British Antarctic Survey (BAS) on behalf of the Government of the South Georgia \& the South Sandwich Islands (GSGSSI); boluses regurgitated by Blue-eyed shag (Leucocarbo georgianus) and Black-browed albatross (Thalassarche melanophris; only 1 sample) breeding on Bird Island, South Georgia $\left(54^{\circ} 00^{\prime} \mathrm{S} 38^{\circ} 03^{\prime} \mathrm{W}\right)$, collected by BAS researchers in 2013 (A. polymorpha: $\mathrm{n}_{\text {Upper }}=10, \mathrm{n}_{\text {Lower }}=15 ;$ P. turqueti: $\mathrm{n}_{\text {Upper }}=12, \mathrm{n}_{\text {Lower }}=15$ ). The animal procedures used in this study were reviewed and approved by the joint BAS Cambridge University Animal Welfare and Ethical Review Committee. Permits to operate were issued by the GSGSSI. Samples were preserved at $-20^{\circ} \mathrm{C}$. At the laboratory, all samples were cleaned and the upper hood length (UHL) and the upper crest length (UCL), from upper beaks, and the lower hood length (LHL) from lower beaks, were measured to the nearest of $0.01 \mathrm{~mm}$ using a digital calliper (bigger items) and a measuring lens in a stereomicroscope (smaller items). Estimated mantle length ( $\mathrm{ML}$ in $\mathrm{mm}$ ) and mass ( $\mathrm{M}$ in $\mathrm{g}$ ) were calculated from loose beaks using allometric equations given by Xavier \& Cherel in 2009 (see Results: Table 1). Even though similar-sized individuals were selected and all beaks used presented sub-adult characteristics (e.g. light-coloured wings), beaks of $P$. turqueti were generally larger than $A$. polymorpha beaks (see in results: Table 1 ; Allcock et al., 2003; Daly and Rodhouse, 1994). Thereafter, samples for stable isotope analysis (A. polymorpha: $\mathrm{n}_{\mathrm{Upper}}=10, \mathrm{n}_{\text {Lower }}=10 ; P$. turqueti: $\mathrm{n}_{\text {Upper }}=10, \mathrm{n}_{\text {Lower }}=10$ ) were kept in $80 \%$ ethanol filled microtubes and the remain samples kept dry until further analyses. 


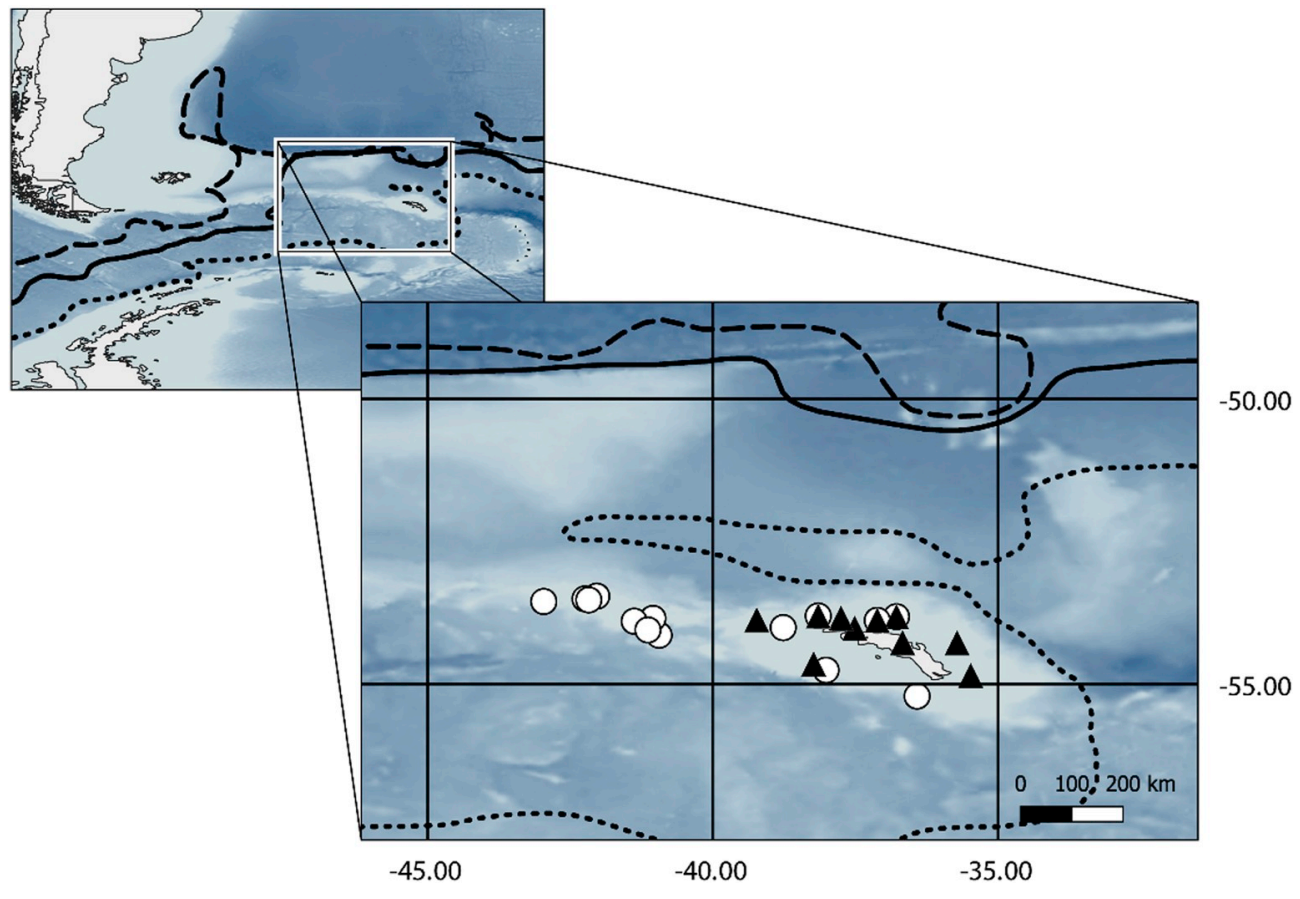

Fig. 1. South Georgia region, where specimens of Adelieledone polymorpha (black triangles) and Pareledone turqueti (white circles) used in this study were caught. In the figure, bathymetry is represented by the background gradient (darker and lighter colours mean deeper and shallower waters respectively) and the oceanic currents - Sub Antarctic Front (dashed line), Antarctic Polar Front (solid line) and the Southern Antarctic Circumpolar Current (pointed line). (For interpretation of the references to colour in this figure legend, the reader is referred to the Web version of this article.)

\subsection{Physical properties of beaks}

To evaluate beak microstructure, the upper and lower beaks of both species were fractured, sputter-coated with gold and observed by scanning electron microscope JSM-6010 LV (JEOL, Japan) (Cárdenas et al., 2004; Miserez et al., 2007, 2008). Respecting the long axis of beaks, longitudinal and transversal observations were set by standard mounting. Backscattered electrons enabled the characterization of chemical composition. Since fracture propagation can be affected by different conditions (e.g. humidity), preliminary tests were carried out to observe which conditions would better preserve the natural morphology of the samples' microstructure (dried in vacuum oven at $37^{\circ} \mathrm{C}$ for $24 \mathrm{~h}$, hydrated from an ethanol-water solution and frozen by immersion on liquid $\mathrm{N}_{2}$ ). Following SEM observations were performed on dried samples as they preserved better the natural microstructure of the beaks (per species, $\mathrm{n}_{\text {Upper }}=2$ and $\mathrm{n}_{\text {Lower }}=2$ ).

Prior to quantitative analysis of crystalline phases, all beak samples (per species, $\mathrm{n}_{\text {Upper }}=1$ and $\mathrm{n}_{\text {Lower }}=1$ ) were dried and ground into powder. Afterwards, the powder pattern was recorded by XRD using a conventional Bragg-Brentano diffractometer (Bruker D8 Advance DaVinci, Germany) operated with a Cu-Ka anode $(\lambda=1.5406 \AA)$. The powder pattern of the bulk material was scanned from $2 \theta$ range between $5^{\circ}$ and $50^{\circ}$ at a speed of $2^{\circ} / \mathrm{min}$ (Cárdenas et al., 2004; Miserez et al., 2007).

Structural features (e.g. geometry and density) of A. polymorpha and $P$. turqueti beaks $\left(\mathrm{n}_{\text {Upper }}=1, \mathrm{n}_{\text {Lower }}=1\right)$ were examined using $\mu C T$, SkyScan 1217 (Bruker, Kontich, Belgium; Ho and Hutmacher, 2006).
For scanning, a voltage range of $50 \mathrm{kV}$ and current source of $200 \mu \mathrm{A}$ were applied. Pixel sizes between $8 \mu \mathrm{m}$ and $16 \mu \mathrm{m}$ were selected for $A$. polymorpha and $P$. turqueti, respectively. No filters were applied on the acquisitions and the rotation of the step used was $0.3^{\circ}$ up to $360^{\circ}$. All 3D images obtained by x-ray diffraction were reconstructed using CTvox software according to a threshold directly proportional to the materials hardness/density.

For nanoindentation tests $(\mathrm{NNI})$, upper beaks $(n=1)$ from both species were prepared by imbedding them in methacrylate resin and polishing by microtomy until the zone of interest (rostrum) was exposed. Nanoindentation tests were performed in a Micro Materials NanoTest equipment in ambient air using a Berkovich tip. The properties of the rostrum were determined by performing indentations along upper beak's exposed longitudinal section, from the rostrum to the end of the hood, determined by interest regions ( 5 in A. polymorpha and 9 in $P$. turqueti) separated by $100 \mu \mathrm{m}$ between each other (Fig. 2). All indentations were performed at a loading rate of $1 \mathrm{mN} / \mathrm{s}$ to a peak of $4 \mathrm{mM}$, held at load for $10 \mathrm{~s}$ and unloaded at $1 \mathrm{mN} / \mathrm{s}$.

\subsection{Stable isotope and mercury analyses}

Stable isotope analyses were performed using beaks of $A$. polymorpha $\left(\mathrm{n}_{\text {Upper }}=10, \mathrm{n}_{\text {Lower }}=10 ; \mathrm{ML}_{\text {Estimated }}=94.37 \pm 24.85 \mathrm{~mm}\right.$; $\mathrm{M}_{\text {Estimated }}=107.21 \pm 36.33 \mathrm{~g}$ wt $)$ and $P$. turqueti $\left(\mathrm{n}_{\mathrm{Upper}}=10\right.$, $\mathrm{n}_{\text {Lower }}=10 ; \quad \mathrm{ML}_{\text {Estimated }}=63.74 \pm 9.15 \mathrm{~mm} ; \mathrm{M}_{\text {Estimated }}=49.47 \pm$ $23.93 \mathrm{~g} \mathrm{wt}$ ) collected from boluses regurgitated by Blue-eyed shag and Black-browed albatross specimens (Xavier and Cherel, 2009). All beaks

Table 1

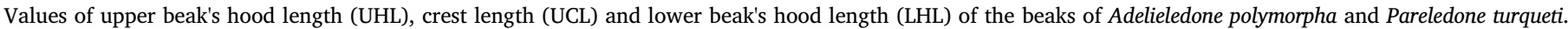

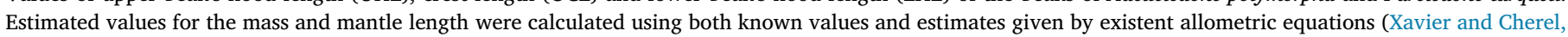
2009). The mean values are presented \pm SD.

\begin{tabular}{|c|c|c|c|c|c|c|c|c|c|c|c|c|c|}
\hline \multirow[t]{3}{*}{ Taxa } & \multicolumn{7}{|c|}{ Upper Beak } & \multicolumn{4}{|c|}{ Lower Beak } & \multirow{3}{*}{$\begin{array}{l}\text { Estimated Mass }(\mathrm{g}) \\
- \\
\text { Mean }\end{array}$} & \multirow{3}{*}{$\begin{array}{l}\text { Estimated Mantle Length }(\mathrm{mm}) \\
\text { Mean }\end{array}$} \\
\hline & \multicolumn{4}{|c|}{ UHL (mm) } & \multicolumn{4}{|l|}{ UCL (mm) } & \multicolumn{3}{|l|}{ LHL (mm) } & & \\
\hline & $\mathrm{n}$ & Mean & Min & Max & Mean & Min & Max & $\mathrm{n}$ & Mean & Min & Max & & \\
\hline A. polymorpha & 40 & $2.90 \pm 0.60$ & 1.47 & 3.93 & $8.73 \pm 1.58$ & 4.27 & 10.51 & 45 & $2.81 \pm 0.65$ & 1.15 & 3.73 & $106.81 \pm 58.94$ & $63.39 \pm 16.42$ \\
\hline P. turqueti & 43 & $5.00 \pm 0.90$ & 2.55 & 6.63 & $11.94 \pm 2.07$ & 5.57 & 15.22 & 46 & $3.73 \pm 0.92$ & 1.25 & 5.91 & $63.40 \pm 32.70$ & $67.38 \pm 12.32$ \\
\hline
\end{tabular}




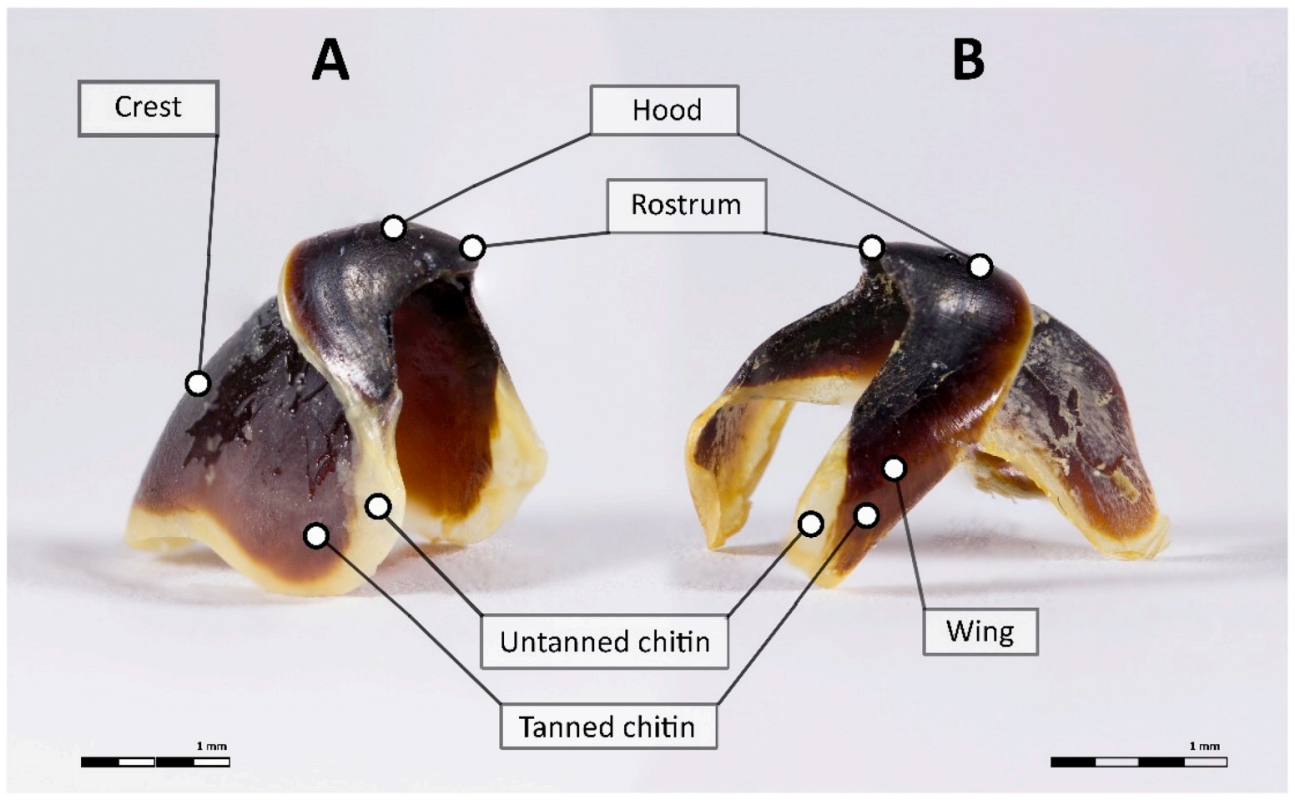

Fig. 2. Legend of octopods' upper (A) and lower (B) beaks. Beaks from a Pareledone turqueti specimen not used in this study. Measures are: Upper Hood Length $(\mathrm{UHL})=4.98 \mathrm{~mm}$; Upper Crest Length $(\mathrm{UCL})=12.53 \mathrm{~mm}$ and Lower Hood Length $(\mathrm{LHL})=3.55 \mathrm{~mm}$.

of A. polymorpha $(\mathrm{UHL}=2.43 \pm 0.72 \mathrm{~mm}, \mathrm{UCL}=6.62 \pm 1.77 \mathrm{~mm}$, $\mathrm{LHL}=2.83 \pm 0.50 \mathrm{~mm}$ ) and $P$. turqueti $(\mathrm{UHL}=4.55 \pm 0.96 \mathrm{~mm}$, $\mathrm{UCL}=10.82 \pm 2.31 \mathrm{~mm}, \quad \mathrm{LHL}=3.45 \pm 0.67 \mathrm{~mm})$ presented subadult characteristics such as not completely darkened crest and wings. Each upper beak was sectioned in two pieces (rostrum's tip and crest, representing juveniles and adult life-stages, respectively (Queirós et al., 2018, Fig. 2). In the lower beaks, one wing (representing adult lifestage, Fig. 2) was sectioned and the remaining beak was analysed as a whole (entire beak without 1 wing). Upper beaks' crest and lower beaks' wing of $A$. polymorpha were divided in tanned and untanned chitin, to assess the influence of chitin composition on stable isotope ratios. Untanned chitin subsamples were not used for habitat and trophic ecology analysis, as differences in protein content between tissues (Miserez et al., 2008) might have an impact on $\delta^{15} \mathrm{~N}$ not only due to their different biochemical composition but also because chitin has a higher $\mathrm{C}$ / $\mathrm{N}$ ratio than protein and is impoverished in ${ }^{15} \mathrm{~N}$ relative to diet (Cherel et al., 2009). As chitinous parts are also impoverished in ${ }^{15} \mathrm{~N}$ relative to other tissues, direct comparisons between the isotope ratios of predator and prey should be prevented. Due to their small mass and size respectively, beak samples used in SIA were different from the ones for trace metal analysis.

Prior to analysis, all beak samples (see $n$ values in Results: Table 2) were dried at $60{ }^{\circ} \mathrm{C}$ for $24 \mathrm{~h}$ and ground into fine powder. Approximately $0.35 \mathrm{mg}$ of each sample was encapsulated. Stable isotope ratios of carbon $\left({ }^{13} \mathrm{C} /{ }^{12} \mathrm{C}\right)$ and nitrogen $\left({ }^{15} \mathrm{~N} /{ }^{14} \mathrm{~N}\right)$ were analysed using a continuous-flow Isotope Mass Spectrometer (CFIRMS). Results were calculated by the formula, $\delta X=\left[\left(\mathrm{R}_{\text {Sample }} / \mathrm{R}_{\text {standard }}\right)-1\right] \times 1000$, where the $X$ represents ${ }^{13} \mathrm{C}$ and ${ }^{15} \mathrm{~N}$, and $\mathrm{R}_{\text {sample }}$ represents the ratios ${ }^{13} \mathrm{C} /{ }^{12} \mathrm{C}$ $\left(\delta^{13} \mathrm{C}\right)$ and ${ }^{15} \mathrm{~N} /{ }^{14} \mathrm{~N}\left(\delta^{15} \mathrm{~N}\right)$. $\mathrm{R}_{\text {standard }}$ represents the Vienna-PeeDee belemnite standard (V-PDB) and the atmospheric $\mathrm{N}_{2}$ (AIR) for $\delta^{13} \mathrm{C}$ and $\delta^{15} \mathrm{~N}$, respectively (Cherel and Hobson, 2005; Hobson and Welch, 1992). Replicate measurements of internal laboratory standards (acetanilide) indicate measurement errors $<0.1 \%$ both for $\delta^{13} \mathrm{C}$ and for $\delta^{15} \mathrm{~N}$.

For mercury analysis, muscle and lower beaks of A. polymorpha and $P$. turqueti were collected from whole individuals caught on bottom trawling surveys. All samples (A. polymorpha: $\mathrm{n}_{\text {Lower }}=10, \mathrm{n}_{\text {Muscle }}=10$; $P$. turqueti: $\mathrm{n}_{\text {Lower }}=10, \mathrm{n}_{\text {Muscle }}=11$ ) were lyophilised during $24 \mathrm{~h}$ and homogenized. T-Hg concentrations were determined by atomic absorption spectrometry, using an Advanced Mercury Analyzer (AMA)

Table 2

Stable isotope $\left(\delta^{13} \mathrm{C}\right.$ and $\left.\delta^{15} \mathrm{~N}\right)$ and $\mathrm{C} / \mathrm{N}$ mass ratios registered values in Adelieledone polymorpha and Pareledone turqueti. Mean $\pm \mathrm{SD}$, minimum and maximum values are shown.

\begin{tabular}{|c|c|c|c|c|c|c|c|c|c|c|}
\hline & & $\delta^{13} \mathrm{C}(\% 0)$ & & & $\delta^{15} \mathrm{~N}(\% 0)$ & & & $\mathrm{C} / \mathrm{N}$ mass ratic & & \\
\hline Species & $\mathrm{n}$ & Mean \pm SD & Min & Max & Mean \pm SD & Min & Max & Mean \pm SD & Min & Max \\
\hline \multicolumn{11}{|l|}{ Adelieledone polymorpha } \\
\hline Lower Beak (Whole) & 10 & $-18.05 \pm 0.61$ & -19.16 & -16.73 & $7.17 \pm 0.57$ & 6.15 & 8.08 & $3.15 \pm 0.06$ & 3.07 & 3.30 \\
\hline \multicolumn{11}{|l|}{ Lower Beak } \\
\hline Wing (Tanned chitin) & 10 & $-18.46 \pm 0.38$ & -19.26 & -17.68 & $7.50 \pm 0.73$ & 5.99 & 8.56 & $3.48 \pm 0.47$ & 2.92 & 4.22 \\
\hline Wing (Untanned chitin) & 6 & $-18.63 \pm 0.70$ & -19.23 & -17.42 & $8.15 \pm 0.97$ & 6.38 & 9.30 & $3.76 \pm 0.20$ & 3.40 & 3.98 \\
\hline \multicolumn{11}{|l|}{ Upper Beak } \\
\hline Rostrum & 9 & $-18.91 \pm 0.44$ & -19.99 & -18.50 & $6.00 \pm 0.44$ & 5.08 & 7.24 & $3.17 \pm 0.13$ & 2.94 & 3.35 \\
\hline Crest (Tanned chitin) & 9 & $-18.58 \pm 0.34$ & -19.26 & -18.07 & $7.01 \pm 0.40$ & 6.50 & 7.70 & $3.35 \pm 0.38$ & 2.87 & 4.26 \\
\hline Crest (Untanned chitin) & 9 & $-18.97 \pm 0.45$ & -19.55 & -17.87 & $7.69 \pm 0.30$ & 6.55 & 8.37 & $3.63 \pm 0.30$ & 3.07 & 4.21 \\
\hline \multicolumn{11}{|l|}{ Pareledone turqueti } \\
\hline Lower Beak (Whole) & 10 & $-18.37 \pm 0.73$ & -19.62 & -17.36 & $6.80 \pm 0.52$ & 6.04 & 7.59 & $3.17 \pm 0.26$ & 2.92 & 3.75 \\
\hline \multicolumn{11}{|l|}{ Upper Beak } \\
\hline Rostrum & 10 & $-18.75 \pm 0.81$ & -19.59 & -16.74 & $6.17 \pm 0.81$ & 5.16 & 7.83 & $3.56 \pm 0.81$ & 3.07 & 4.63 \\
\hline Crest & 9 & $-18.95 \pm 1.13$ & -20.55 & -16.49 & $7.84 \pm 0.65$ & 7.01 & 9.02 & $3.76 \pm 0.56$ & 3.10 & 4.93 \\
\hline
\end{tabular}


LECO 254, with thermal decomposition and gold amalgamation (Seco et al., 2019; Xavier et al., 2016). The detection limit of the equipment is $0.01 \mathrm{ng}$ and the accuracy of the analysis was verified using mussel tissue (ERM - CE278K; $97 \pm 16 \%$ ) as certified reference material (CRM) for calculating recovery efficiency. Analyses were performed in duplicate, when possible, blanks were analysed at the beginning of each set of samples and the coefficient of variation between replicates never exceeded $10 \%$.

\subsection{Statistical analysis}

Mass (M) and mantle length (ML) allometric equations were calculated (see in results: Table 1) using Pearson's Correlation from individuals with available $\mathrm{M}$ values (A. polymorpha, $\mathrm{n}=37, P$. turqueti, $\mathrm{n}=24$ ) and, only for those individuals, differences in M, UHL, UCL and LHL were checked between species using T-tests. For the rest of the beaks used in this study (i.e. not collected from whole individuals) the $\mathrm{M}$ and ML values were estimated using the allometric equations given by Xavier and Cherel (2009). The results of the physical properties' analysis are mainly qualitative thus a descriptive and comparative interpretation of the output is provided between beak type (upper or lower) and species. For the NNI results, one-way ANOVA's were performed to determine statistically significant differences $(p<0.05)$ between the samples after meeting the assumption of normality (Kolmogorov-Smirnov), using the GraphPad Prism 6 (GraphPad Software, La Jolla California USA). Regarding SIA, a series of one-way ANOVA's were used to assess differences in $\delta^{13} \mathrm{C}$ and $\delta^{15} \mathrm{~N}$ between tanned and untanned chitin and a multivariate ANOVA was performed using species and beak region (rostrum and crest) as grouping variables. The carbon and nitrogen isotopic niche overlap were calculated using Stable Isotope Bayesian Ellipses in R (SIBER) encompassing 95\% of the proportion of data. For the mercury analysis, one-way ANOVA's were performed to check significant differences between species and soft/ hard tissues (muscle/beak, respectively). No correlations between mercury and stable isotopes were performed since the beak samples used were not from the same individuals. Excluding NNI results, the normality of data was tested using Shapiro-Wilks test and statistical analyses performed using R software (R Core Team, 2019).

\section{Results}

Only for beaks collected from whole individuals with available mass data, significant differences between species were recorded on UHL $(\mathrm{t}=11.77, \mathrm{p}<0.001)$, UCL $(\mathrm{t}=8.48, \mathrm{p}<0.001)$ and LHL $(\mathrm{t}=6.70$, $\mathrm{p}<0.001$ ), showing that for individuals with similar mass, the upper and lower beaks of $A$. polymorpha $(\mathrm{n}=37)$ are generally smaller relative to $P$. turqueti $(\mathrm{n}=24)$. Some allometric equations were calculated, since strong correlations were found in both species between LHL and the mass $\left(P\right.$. turqueti: $\mathrm{LnM}=0.7756+2.4659$ LnLHL $\left[\mathrm{r}^{2}=0.738\right.$, $\mathrm{n}=24]$; A. polymorpha: $\mathrm{M}=-98.327+72.602$ LHL $\left[\mathrm{r}^{2}=0.837\right.$, $\mathrm{n}=37]$ ) and mantle length (A. polymorpha: LnML $=2.9628+1.511$ LnLHL $\left.\left[r^{2}=0.969, \mathrm{n}=5\right]\right)$.

\subsection{Physical properties}

A similar compact and chemically homogenous structure was observed in transversal and longitudinal fractures of both species' upper and lower beaks. Between the inner and outer surface of the beaks, it was also possible to distinguish two strongly-linked layers with different structural arrangements (Fig. 3) and only in the outer surface, spherical and fibrillary structures were recorded. In addition, through XRD spectra (Fig. 4) beaks of $A$. polymorpha and $P$. turqueti were mainly amorphous structures composed by $\alpha$-chitin, the only crystalline phase found, manifested by the intense peaks at $20=9$ and $19^{\circ}$ and weak peaks at 12,23 and $27^{\circ}$. Also, $\mu \mathrm{CT}$ scans confirmed that both upper and lower beaks are very compact structures without porosities, increasing in density from peripheral to core regions of the beak. Not precisely quantifiable, beaks of $A$. polymorpha are sharper and less dense relative to $P$. turqueti beaks (Fig. 5). Regarding A. polymorpha and $P$. turqueti, both Hardness and Young's Modulus values are statistically different ( $\mathrm{p}<0.05$ ) when comparing the tip of the rostrum (region 1 ) with the end of the hood (region 5 and 9, respectively). Moreover, the single upper beak of $P$. turqueti was significantly harder (Hardness $=0.269 \mathrm{GPa}$; Young's Modulus $=4.99 \mathrm{GPa})(\mathrm{p}<0.05)$ than the beak of $A$. polymorpha (Hardness $=0.253 \mathrm{GPa}$; Young's Modulus = 4.69) (Fig. 6).

\subsection{Habitat and trophic niche}

Differences between tanned ( $\left.\mathrm{n}_{\text {Upper }}=9, \mathrm{n}_{\text {Lower }}=10\right)$ and untanned $\left(\mathrm{n}_{\mathrm{Upper}}=6, \mathrm{n}_{\text {Lower }}=9\right)$ chitin stable isotopes, ${ }^{12} \mathrm{C} /{ }^{13} \mathrm{C}$ and ${ }^{14} \mathrm{~N} /{ }^{15} \mathrm{~N}$, and $\mathrm{C} / \mathrm{N}$ ratios were assessed in A. polymorpha upper and lower beaks (Table 2). Differences were only found in upper beaks' $\delta^{15} \mathrm{~N}$ values $\left(F_{1,17}=7.73, p=0.010\right)$ and only beak sections of tanned chitin were used in subsequent analyses to avoid biased results. An isotopic niche overlap of $79.5 \%$ was found, showing no significant differences between the isotopic values of both species' lower beaks $\left(\mathrm{n}_{\text {Ind }}=10\right)$ $\left(\mathrm{F}_{1,18}=0.79, \mathrm{p}=0.52\right)$. A significant enrichment of $\delta^{15} \mathrm{~N}$ was found from the rostrum to the crest of the upper beaks of A. polymorpha $\left(\mathrm{n}_{\text {rostrum }}=9, \mathrm{n}_{\text {crest }}=9\right)$ and $P$. turqueti $\left(\mathrm{n}_{\text {rostrum }}=10, \mathrm{n}_{\text {crest }}=9\right)$ $\left(F_{1,32}=16,85, p<0.001\right)$. No differences were found between species and between rostrum and crest $\delta^{13} \mathrm{C}$ values. Between $A$. polymorpha $\left(\mathrm{n}_{\text {crest }}=9\right)$ and $P$. turqueti $\left(\mathrm{n}_{\text {crest }}=9\right)$, an isotopic niche overlap of $19.2 \%$ of the upper beak's crest subsamples $\left(\mathrm{F}_{1,16}=4.08, \mathrm{p}=0.03\right)$ was found, but only $\delta^{15} \mathrm{~N}$ values showed to be significantly different $\left(\mathrm{F}_{1,16}=9.05, \mathrm{p}=0.01\right)$, with the crest region of the beak presenting higher levels of ${ }^{15} \mathrm{~N}$ relative to the rostrum (Fig. 7).

\subsection{Trace metal analysis}

Mercury concentrations found in muscle were $6\left(\mathrm{~F}_{1,12}=50.96\right.$, $\mathrm{p}<0.001$; A. polymorpha, $\mathrm{n}=10)$ and 10 times $\left(\mathrm{F}_{1,14}=55.43\right.$, $\mathrm{p}<0.001$; $P$. turqueti, $\mathrm{n}=11$ ) higher than concentrations in lower beaks. The muscle $\mathrm{T}-\mathrm{Hg}$ concentrations of $A$. polymorpha $\left(0.322 \pm 0.088 \mu \mathrm{g} \mathrm{g}^{-1}\right)$ were significantly lower $\left(\mathrm{F}_{1,19}=5.38\right.$, $\mathrm{p}=0.03)$ than $P$. turqueti $\left(0.434 \pm 0.128 \mu \mathrm{g} \mathrm{g}^{-1}\right)$ whilst, T-Hg concentrations on $A$. polymorpha lower beaks $\left(0.052 \pm 0.008 \mu \mathrm{gg}^{-1}\right)$ were significantly higher $\left(\mathrm{F}_{1,19}=13.09, \mathrm{p}=0.002\right)$ than $P$. turqueti $\left(0.038 \pm 0.008 \mu \mathrm{g} \mathrm{g}^{-1}\right.$; Fig. 8). For both octopod species, no correlations were found between $\mathrm{T}-\mathrm{Hg}$ concentrations of both tissues and between tissues and LHL.

\section{Discussion}

\subsection{Physical properties of the beaks of A. polymorpha and P. turqueti}

Regarding physical properties, similar chemical compositions and microstructure were expected to be found in both species' beaks. However, contrary to the lamellar structure observed in squid beaks (Miserez et al., 2007), the upper and lower beaks of both octopod species present a similar and very compact structure composed by two different structural arrangements (Fig. 3), suggesting that both beaks possess similar function when taking prey. The fibrillary and spherical structures observed on the inner surfaces of both species' beaks seem to have a protein origin and to not affect adjacent beak's microstructure. From backscattered electrons, the chemical composition of both beaks of $A$. polymorpha and $P$. turqueti appears to be homogenous. XRD spectra confirmed that both octopod beaks present a similar amorphous structure constituted by only one crystalline phase found, $\alpha$-chitin (Fig. 4). Prior XRD studies show that $\beta$ and $\alpha$-chitin can be found in squid beaks (Miserez et al., 2007) and also in crustacean shells (Cárdenas et al., 2004). In addition, $\mu$ CT's indicate that both species' 

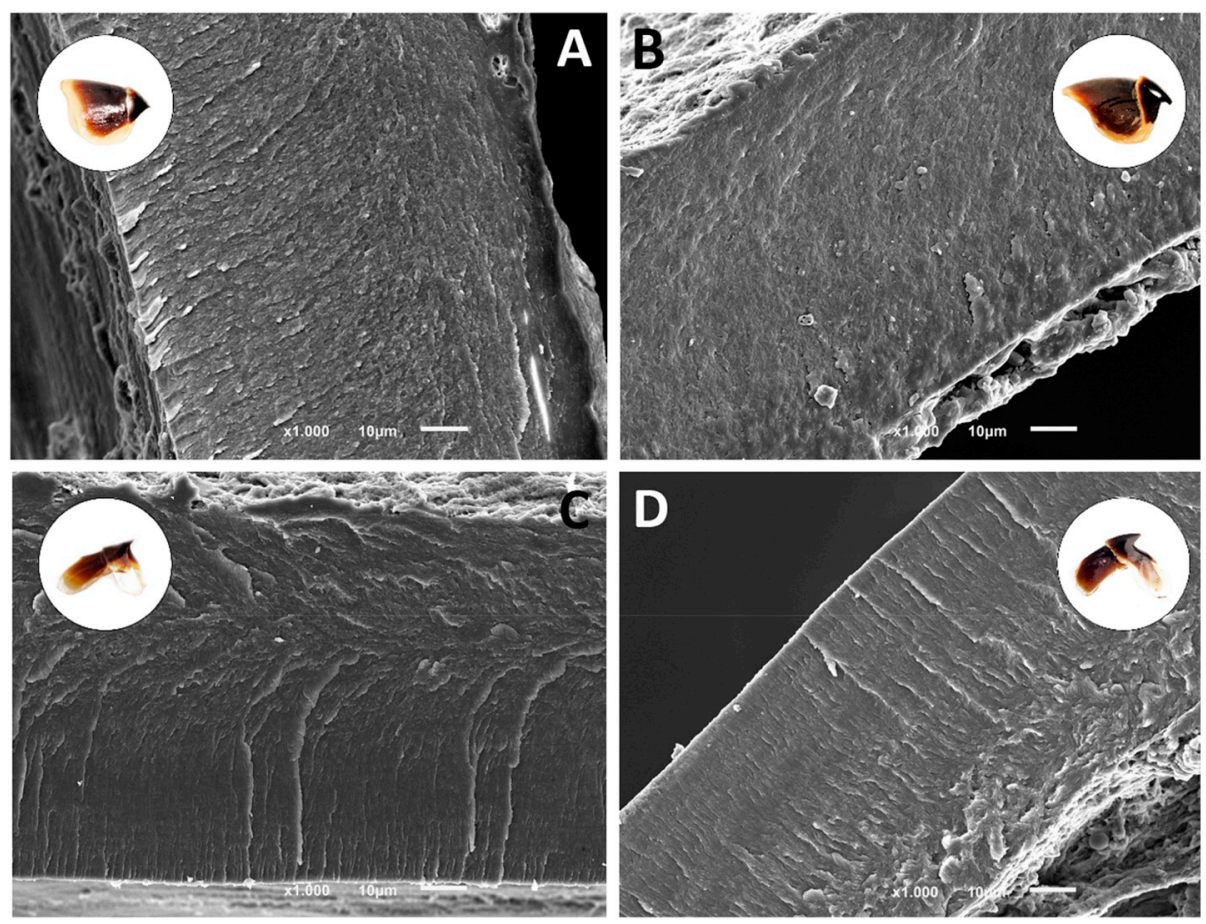

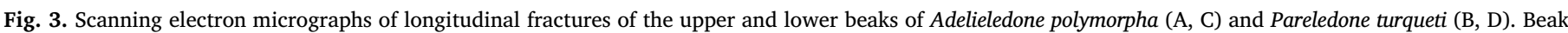
pictures were adapted from Xavier and Cherel (2009).

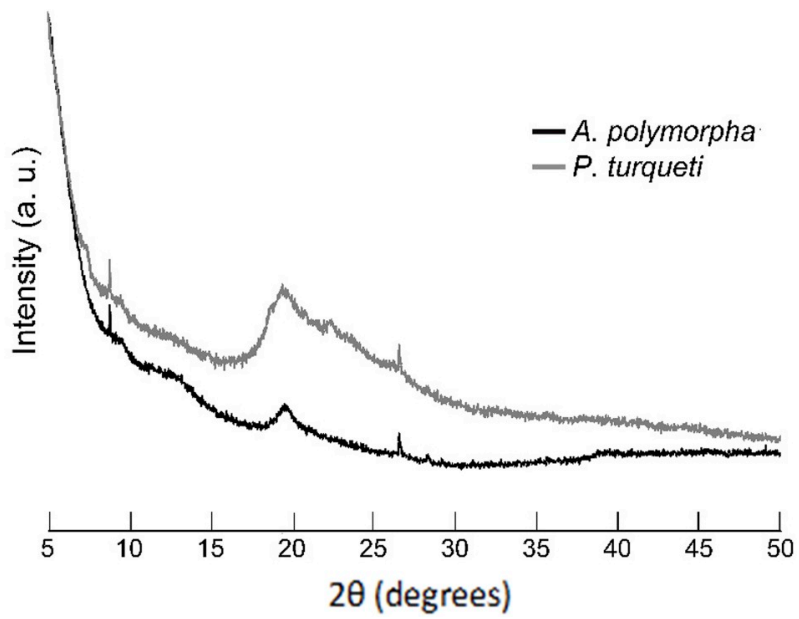

Fig. 4. The XRD spectra (dispersion range 20 of $5-50^{\circ}$ ) comparing the beak structure of Adelieledone polymorpha ( $\mathrm{M}=145 \mathrm{~g} \mathrm{wt})$ and Pareledone turqueti $(\mathrm{M}=57 \mathrm{~g} \mathrm{wt})$. Beak measures (mm): A. polymorpha - Upper Hood Length $(\mathrm{UHL})=3.73$, Upper Crest Length $(\mathrm{UCL})=8.60$ and Lower Hood Length $(\mathrm{LHL})=3.29 ;$. turqueti $-\mathrm{UHL}=4.11, \mathrm{UCL}=11.76$ and $\mathrm{LHL}=3.81$.

beaks are very compact and free of porous structures (Fig. 5).

The most noticeable differences between beaks of both species are their different morphology and structural density which seems to affect the hardness and stiffness of the beak. The unique beak of A. polymorpha seems to be structurally less dense and sharper relative to the beak of $P$. turqueti, which has a bulky shape very similar to those found in other benthic octopod species that feed on hard-shelled prey (Guerra and Nixon, 1987). Mechanical properties of the beaks may be related to the differences between the feeding ecology of the two octopod species. In fact, reported differences are in agreement with previous studies that found hard-shelled organisms exclusively in the diet of $P$. turqueti, being prey that require stronger beaks for hunting and feeding (Daly, 1996). Considering the only single upper beak as representative of the species, the harder and stiffer beak of $P$. turqueti supports a generalist feeding behaviour. Beak values of hardness and stiffness of the jumbo squid Dosidicus gigas, a generalist predator which feeds on fish, crustaceans and cephalopods (Nigmatullin et al., 2001), are roughly the double of the ones observed for A. polymorpha and $P$. turqueti when comparing with the values reported by Miserez and his colleagues, in 2007. These differences may be related to the different $\beta$-chitin based microstructure with a lamellar organization as well as with the larger size of the analysed beaks for that study and, for that reason, future studies may be needed to address ontogenetic variations in the physical properties of the beaks.

Besides the different beak morphology, previous studies reported dissimilarities between the digestive apparatus of A. polymorpha and $P$. turqueti (Allcock et al., 2003) indicating that both species might be adapted to different trophic niches. For instance, the posterior salivary gland (PSG), responsible for producing toxic saliva, is significantly larger in A. polymorpha, indicating the venom's importance for the species' feeding behaviour (Gibbs and Greenaway, 1978; Undheim et al., 2010). On the other hand, the large-sized buccal mass of $P$. turqueti enables stronger bites and, consequently, the exploration of a wider range of prey unavailable to A. polymorpha (Allcock et al., 2003; Daly and Rodhouse, 1994; Piatkowski et al., 2003). Moreover, taking into account that $A$. polymorpha presents a less muscular body relative to $P$. turqueti, the dissimilarities between species suggest that $A$. polymorpha is adapted to exploit a specific trophic niche in the water column (Daly and Rodhouse, 1994).

\subsection{Habitat and trophic niche of A. polymorpha and P. turqueti}

Establishing gradients of $\delta^{13} \mathrm{C}$ for the South Georgia region can be a difficult task since $\delta^{13} \mathrm{C}$ values can vary spatially (i.e. not linearly related with the latitude and/or inshore/offshore gradients), from -19 to $-23 \%$, both at the base of the trophic web and at the consumers level, due to the encounter of various water masses and fronts (i.e. Southern Antarctic Circumpolar Current Front, South Georgia shelf water, Antarctic Zone water) around South Georgia (Brault et al., 2018; Ceia et al., 2015; Stowasser et al., 2012). However, since A. polymorpha and $P$. turqueti are sympatric, holobenthic (Barratt et al., 2008) and no 

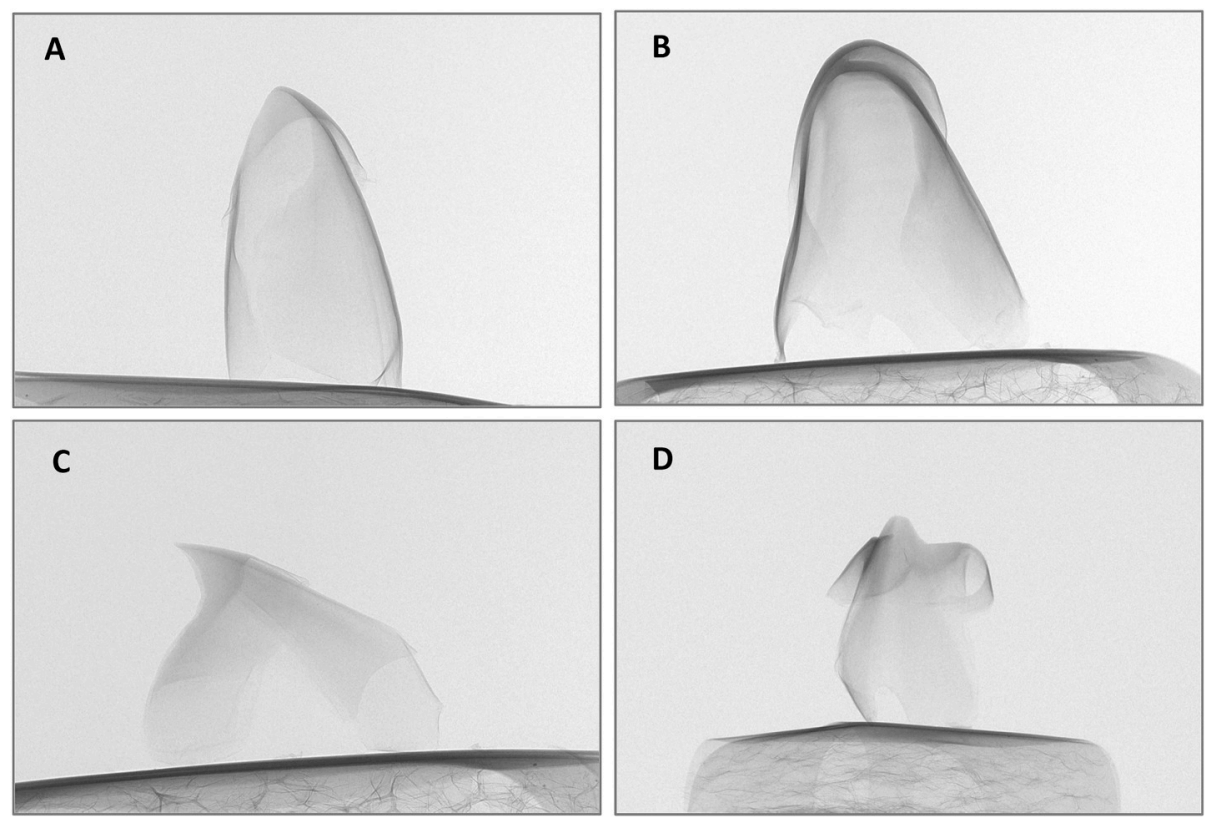

Fig. 5. Micro CT scans of the beak structure of Adelieledone polymorpha (A - Upper; C - Lower) and Pareledone turqueti (B - Upper; D - Lower). Beak measures (mm): A. polymorpha - Upper Hood Length $(\mathrm{UHL})=5.83$, Upper Crest Length $(\mathrm{UCL})=13.99$ and Lower Hood Length $(\mathrm{LHL})=4.52 ;$. turqueti $-\mathrm{UHL}=2.59, \mathrm{UCL}=8.65$ and $\mathrm{LHL}=3.23$.
A. polymorpha
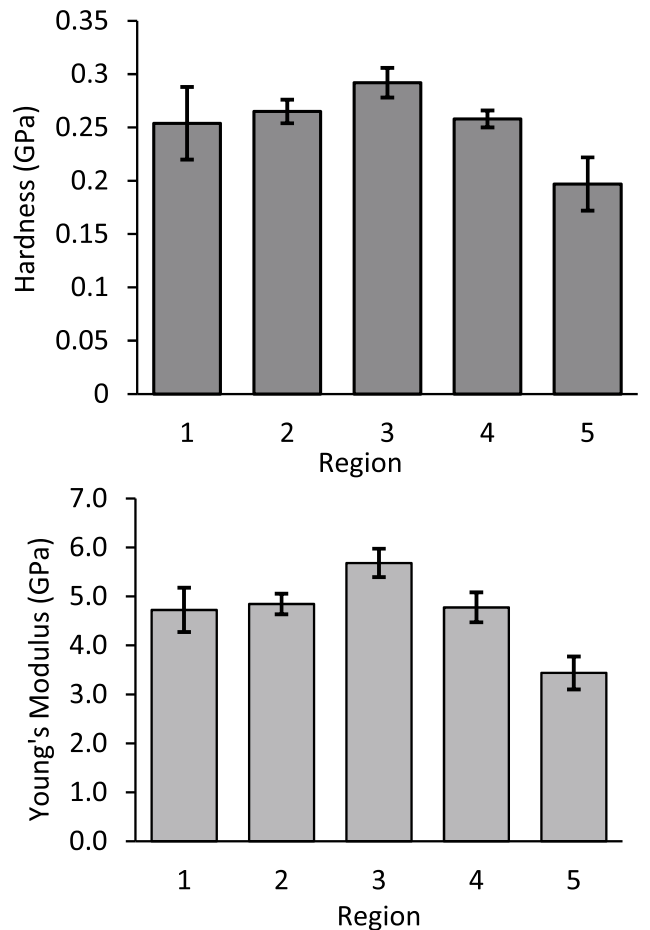

P. turqueti
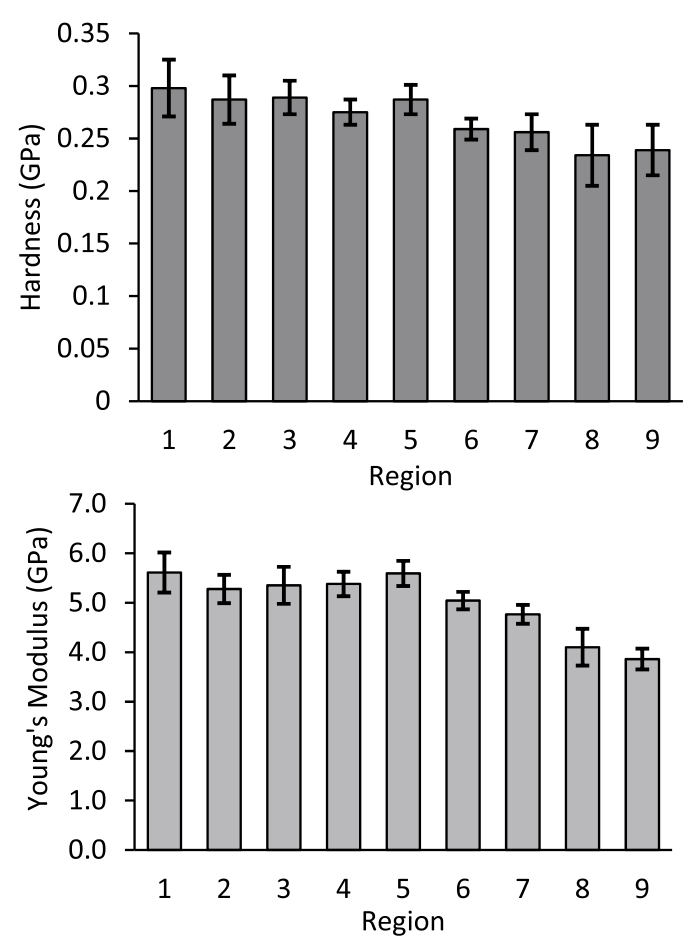

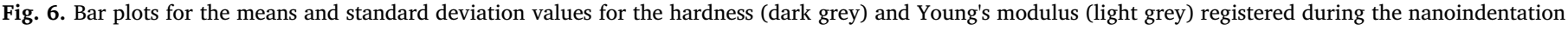

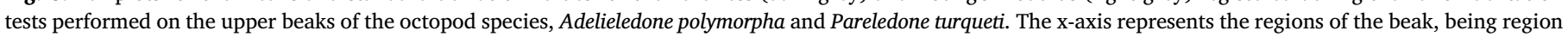

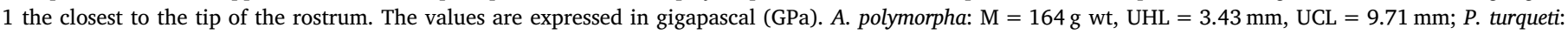
$\mathrm{M}=82 \mathrm{~g}$ wt, $\mathrm{UHL}=6.25 \mathrm{~mm}$ and $\mathrm{UCL}=14.23 \mathrm{~mm}$.

significant differences were found between $\delta^{13} \mathrm{C}$ values registered in the juvenile and adult stages (represented by the beak's rostrum and crest, respectively), of both species, it is hypothesized that both species occupy the benthic ecosystems around South Georgia throughout their lifecycles. Regarding trophic niches, an enrichment in $\delta^{15} \mathrm{~N}$ from juvenile to adult life stages was expected for both species, since preys of bigger size and of higher trophic levels become available as individuals grow (Cherel and Hobson, 2005; Guerra et al., 2010). Even though $\delta^{15} \mathrm{~N}$ values can vary geographically from bottom to top trophic levels (Alvito et al., 2014; Guerreiro et al., 2015; Seco et al., 2016), A. polymorpha and $P$. turqueti inhabit the same ecosystems thus having identical background carbon and nitrogen isotope signatures.

Significant differences found on upper beak's crest $\delta^{15} \mathrm{~N}$ values suggest that $A$. polymorpha and $P$. turqueti explore different trophic niches during their adult life stage. Even though no differences were found on $\delta^{15} \mathrm{~N}$ values for lower beaks, different isotope signatures have 


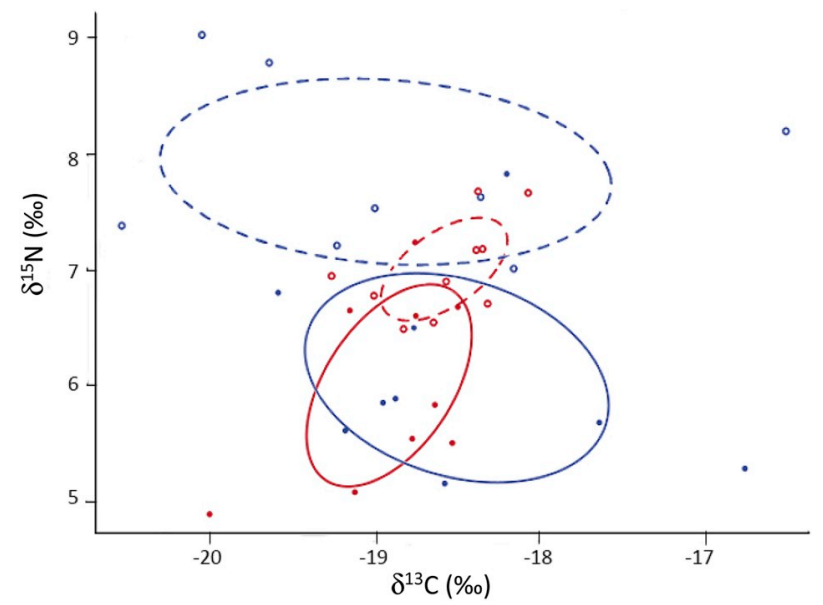

Fig. 7. Bivariate $\delta^{13} \mathrm{C}$ and $\delta^{15} \mathrm{~N}$ plot for upper beaks' rostrum (solid lines and filled circles) and crest (dashed lines and empty circles) of Adelieledone polymorpha (red) and Pareledone turqueti (blue), estimated by the ellipse corrected for the SIBER analysis. Samples of untanned chitin were excluded from this analysis. (For interpretation of the references to colour in this figure legend, the reader is referred to the Web version of this article.)

been recorded between individuals' upper and lower beak (Cherel and Hobson, 2005) and a recent study suggests that upper beaks present isotopic signatures more reliable to be used in trophic models, as lower beaks present a slower growing rate which makes harder to study isotopic signatures of specific periods (Queirós et al., 2018). For that reason, we are confident that both species might occupy partially different trophic niches, differing in some prey items available in function of the adaptations that both species present, such as the different physical properties of the beak, buccal mass and posterior salivary gland size. Interpretation of mercury results can also give as insight about trophic differences (see next topic).

\subsection{Mercury in A. polymorpha and P. turqueti in relation to other octopods}

The Southern Ocean has some of the highest concentrations of organic $\mathrm{Hg}$ (the most toxic form of mercury) reported for open waters (Cossa et al., 2011), although information regarding $\mathrm{Hg}$ levels on Antarctic cephalopods is scarce. To our knowledge, this study is the first to tackle $\mathrm{Hg}$ concentrations on Antarctic octopods and to compare it on muscle and beaks. T-Hg concentrations found in the muscle of $P$. turqueti are higher relative to those found in A. polymorpha. Since mercury is biomagnified throughout the trophic web, with top predators presenting higher concentrations, $\mathrm{T}-\mathrm{Hg}$ analysis suggests that $P$. turqueti feeds on preys of higher trophic levels than A. polymorpha, corroborating with the $\delta^{15} \mathrm{~N}$ results. On the other hand, A. polymorpha presented higher $\mathrm{T}-\mathrm{Hg}$ concentrations regarding the lower beaks. Apparently, lower beaks also presented 6 to 10 times less T-Hg levels relative to muscle, similar values also found on several Antarctic squid species (Xavier et al., 2016). As mercury intake rates and elimination processes can vary between tissues and species (Penicaud et al., 2017; Seixas et al., 2005), any comparative ecological interpretations regarding habitat and trophic niches should be considered with caution. Future studies should consider correlating mercury with nitrogen stable isotope ratios.

Since benthic organisms tend to accumulate $\mathrm{Hg}$ due to living close to the sediment, were this element is more bioavailable (Bargagli et al., 1998; Bustamante et al., 2006), the T-Hg values registered in lower beaks and muscle of $A$. polymorpha and $P$. turqueti were higher (3-5 times higher) than the ones registered in lower beaks and muscle of some Antarctic squid species with more pelagic behaviour (see Supporting Information, Table A1). When compared with other octopods, concentrations of T-Hg found in the muscle of A. polymorpha and $P$. turqueti were similar to those registered in muscle of other northern hemisphere octopod species (see Supporting Information, Table A2). Moreover, cephalopods are among the most contaminated prey (Cipro et al., 2018) of marine top predators, such as Antarctic seabirds, which seem to rely heavily on these prey containing high $\mathrm{Hg}$ levels (Anderson et al., 2009). Establish a base line of mercury concentration for cephalopods is important to understand this contaminant in the Southern Ocean trophic webs. Therefore, evaluating how mercury accumulates on cephalopod tissues (e.g. muscle and beaks) may be a good tool to estimate $\mathrm{Hg}$ body burden on cephalopods, and how much $\mathrm{Hg}$ concentration magnifies along the trophic chain.

\section{Conclusion}

As a warming trend has been recorded in South Georgia region (Whitehouse et al., 2008), understanding how ecosystems are going to respond due to environmental change has become increasingly important in the development of future policy strategies. As South Georgia region is within the northern boundary of the distribution of A. polymorpha and $P$. turqueti, the complexity of ecosystems and multiplicity of stressors make environmental impacts very hard to predict. Through our study, we confirmed that both species inhabit the benthic ecosystems of South Georgia during their lifecycle. According to literature, the low dispersal of the species may be rooted in their reproductive strategies (Barratt et al., 2008; Villanueva and Norman, 2008). Moreover, both $A$. polymorpha and $P$. turqueti deal with interspecific competition by occupying overlapping trophic niches, but with some differences. While $P$. turqueti is able to feed on hard-shelled mollusks, such as bivalves, and crustaceans due to its harder beak, A. polymorpha has an unique beak morphology more suitable for predating organisms of softer tissues (Allcock et al., 2003; Daly, 1996; Daly and Rodhouse,
Flesh

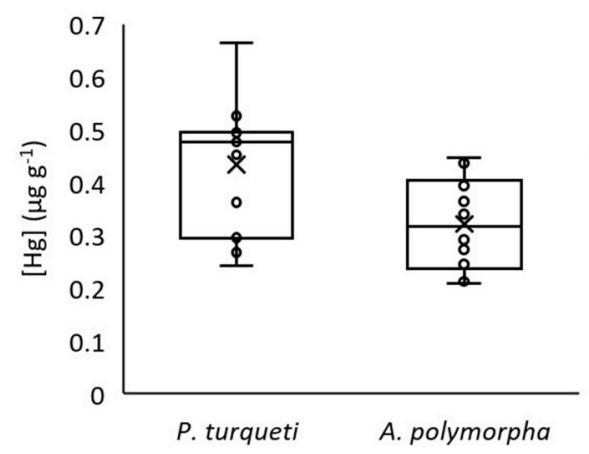

Lower Beak

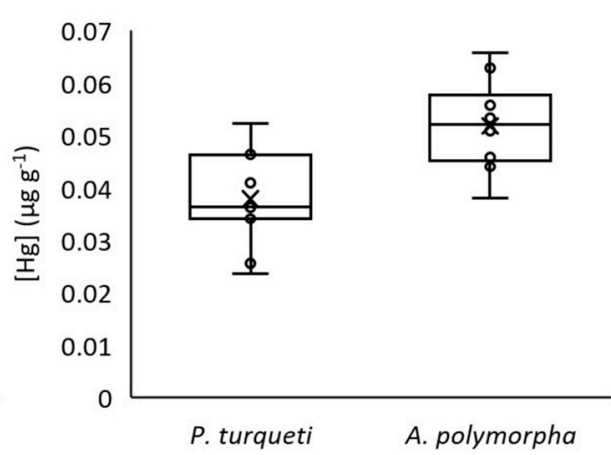

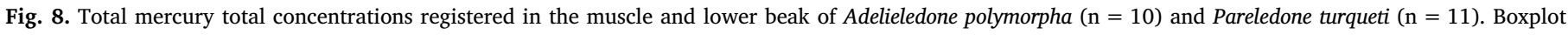
shows the mean (cross), median (line), 1st/3rd quartile (box), minimum/maximum (whiskers) and concentration values (circles) registered. 
1994; Piatkowski et al., 2003). Different feeding strategies may also determine which one will be more successful in the changing future, as A. polymorpha seems to rely heavily on its highly cold-adapted venom (i.e. bigger PSG; Undheim et al., 2010) while P. turqueti predates by using its stronger muscles of the buccal mass and bulkier beak. Since both octopods are highly abundant and a major prey for some top predators breeding in South Georgia region, understanding their ecology, and using them as bioindicators (i.e. high abundance, opportunistic behavior and short lifecycle), can be a powerful tool contributing to fill existing gaps of knowledge and reinforcing the status of protected areas in this region.

\section{Acknowledgements}

The authors thank to Dr. Mark Belchier from the British Antarctic Survey for assisting in the collection of the specimens for this work. Many thanks to 3B's Research Group (University of Minho) and MAREFOZ who were responsible for analysing the physical properties of beaks and stable isotope signatures. A special thank you to our colleague José Queirós from MARE-UC (Coimbra, Portugal) for his suggestions and guidance. A debt of gratitude is also owed to Dr. A. Louise Allcock (NUI Galway) for her useful guidelines. This work is an international effort under the Scientific Committee on Antarctic Research (SCAR) associated programs, expert and action groups, namely SCAR AnT-ERA, SCAR EGBAMM and ICED. J.C. Xavier was supported by the Investigator Programme (IF/00616/2013) of the Foundation for Science and Technology (FCT-Portugal) and PROPOLAR, and F.R. Ceia was supported by a postdoctoral fellowship (SFRH/BPD/95372/2013) attributed by FCT-Portugal and the European Social Fund (POPH, EU). This study benefited from the strategic program of MARE, financed by FCT-Portugal (MARE- UID/MAR/04292/2019). We also acknowledge FCT-Portugal through a PhD grant to J. Seco (SRFH/PD/BD/113487).

\section{Appendix A. Supplementary data}

Supplementary data to this article can be found online at https:// doi.org/10.1016/j.marenvres.2019.104757.

\section{References}

Allcock, A.L., 1997. The Genetics and Taxonomy of Southern Ocean Octopodidae, with Special Reference to the Genus Pareledone. University of Liverpool, UK.

Allcock, A.L., Hochberg, F.G., Rodhouse, P.G., Thorpe, J.P., 2003. Adelieledone, a new genus of octopodid from the Southern Ocean. Antarct. Sci. 15 (4), 415-424. https:// doi.org/10.1017/S0954102003001512.

Alvito, P.M., Rosa, R., Phillips, R.A., Cherel, Y., Ceia, F.R., Guerreiro, M., et al., 2014. Cephalopods in the diet of nonbreeding black-browed and grey-headed albatrosses from South Georgia. Polar Biol. 38 (5), 631-641. https://doi.org/10.1007/s00300014-1626-3.

Anderson, O.R.J., Phillips, R.A., McDonald, R.A., Shore, R.F., McGill, R.A.R., Bearhop, S., 2009. Influence of trophic position and foraging range on mercury levels within a seabird community. Mar. Ecol. Prog. Ser. 375, 277-288. https://doi.org/10.3354/ meps07784.

Atwell, L., Hobson, K.A., Welch, H.E., 1998. Biomagnification and bioaccumulation of mercury in an arctic marine food web: insights from stable nitrogen isotope analysis. Can. J. Fish. Aquat. Sci. 55 (5), 1114-1121. https://doi.org/10.1139/f98-001.

Bargagli, R., Monaci, F., Sanchez-Hernandez, J.C., Cateni, D., 1998. Biomagnification of mercury in an Antarctic marine coastal food web. Mar. Ecol. Prog. Ser. 169, 65-76. https://doi.org/10.3354/meps169065.

Barratt, I.M., Johnson, M.P., Collins, M.A., Allcock, A.L., 2008. Female reproductive biology of two sympatric incirrate octopod species, Adelieledone polymorpha (Robson 1930) and Pareledone turqueti (Joubin 1905) (Cephalopoda: octopodidae), from South Georgia. Polar Biol. 31, 583-594.

Bennice, C.O., Rayburn, A.P., Brooks, W.R., Hanlon, R.T., 2019. Fine-scale habitat partitioning facilitates sympatry between two octopus species in a shallow Florida lagoon. Mar. Ecol. Prog. Ser. 609, 151-161. https://doi.org/10.3354/meps12845.

Brault, E.K., Koch, P.L., McMahon, K.W., Broach, K.H., Rosenfield, A.P., Sauthoff, W., et al., 2018. Carbon and nitrogen zooplankton isoscapes in West Antarctica reflect oceanographic transitions. Mar. Ecol. Prog. Ser. 593, 29-45. https://doi.org/10. 3354/meps12524

Bustamante, P., Lahaye, V., Durnez, C., Churlaud, C., Caurant, F., 2006. Total and organic $\mathrm{Hg}$ concentrations in cephalopods from the North Eastern Atlantic waters: influence of geographical origin and feeding ecology. Sci. Total Environ. 368 (2-3), 585-596. https://doi.org/10.1016/j.scitotenv.2006.01.038.

Cárdenas, G., Cabrera, G., Taboada, E., Miranda, S.P., 2004. Chitin characterization by SEM, FTIR, XRD, and 13C cross polarization/mass angle spinning NMR. J. Appl. Polym. Sci. 93 (4), 1876-1885. https://doi.org/10.1002/app.20647.

Ceia, F.R., Ramos, J.A., Phillips, R.A., Cherel, Y., Jones, D.C., Vieira, R.P., Xavier, J.C., 2015. Analysis of stable isotope ratios in blood of tracked wandering albatrosses fails to distinguish a $813 \mathrm{C}$ gradient within their winter foraging areas in the southwest Atlantic Ocean. Rapid Commun. Mass Spectrom. 29, 2328-2336.

Cherel, Y., Fontaine, C., Jackson, G.D., Jackson, C.H., Richard, P., 2009. Tissue, ontogenic and sex-related differences in $\delta 13 \mathrm{C}$ and $\delta 15 \mathrm{~N}$ values of the oceanic squid Todarodes filippovae (Cephalopoda: ommastrephidae). Mar. Biol. 156 (4), 699-708. https://doi. org/10.1007/s00227-008-1121-x.

Cherel, Y., Hobson, K.A., 2005. Stable isotopes, beaks and predators: a new tool to study the trophic ecology of cephalopods, including giant and colossal squids. Biol. Sci./ Proc. Roy. Soc. 272 (1572), 1601-1607. https://doi.org/10.1098/rspb.2005.3115.

Cherel, Y., Hobson, K.A., 2007. Geographical variation in carbon stable isotope signatures of marine predators: a tool to investigate their foraging areas in the Southern Ocean. Mar. Ecol. Prog. Ser. 329, 281-287. https://doi.org/10.3354/meps329281.

Cipro, C.V.Z., Cherel, Y., Bocher, P., Caurant, F., Miramand, P., Bustamante, P., 2018 Trace elements in invertebrates and fish from Kerguelen waters, southern Indian Ocean. Polar Biol. 41 (1), 175-191. https://doi.org/10.1007/s00300-017-2180-6.

Collins, M.A., Allcock, A.L., Belchier, M., 2004. Cephalopods of the South Georgia slope. J. Mar. Biol. Assoc. U. K. 84, 415-419. https://doi.org/10.1017/ S0025315404009373h.

Collins, M.A., Rodhouse, P.G., 2006. Southern Ocean cephalopods. Adv. Mar. Biol. 50 (5), 191-265. https://doi.org/10.1016/S0065-2881(05)50003-8.

Constable, A.J., Melbourne-Thomas, J., Corney, S.P., Arrigo, K.R., Barbraud, C., Barnes, D.K.A., et al., 2014. Climate change and Southern Ocean ecosystems I: how changes in physical habitats directly affect marine biota. Glob. Chang. Biol. 20 (10), 3004-3025. https://doi.org/10.1111/gcb.12623.

Cossa, D., Heimbürger, L.E., Lannuzel, D., Rintoul, S.R., Butler, E.C.V., Bowie, A.R., et al., 2011. Mercury in the Southern Ocean. Geochem. Cosmochim. Acta 75 (14), 4037-4052. https://doi.org/10.1016/j.gca.2011.05.001.

Daly, H.I., 1996. Ecology of Antarctic octopus Pareledone from the Scotia Sea. University of Aberdeen.

Daly, H.I., Rodhouse, P.G., 1994. Comparative morphology of two sympatric Pareledone species from South Georgia. Antarct. Sci. 6 (2), 163-169. https://doi.org/10.1017/ S0954102094000258.

Gibbs, P.J., Greenaway, P., 1978. Histological structure of the posterior salivary glands in the blue ringed octopus Hapalochlaena maculosa Hoyle. Toxicon 16 (1), 59-70. https://doi.org/10.1016/0041-0101(78)90061-2.

Guerra, A., Nixon, M., 1987. Crab and mollusc shell drilling by Octopus vulgaris (Mollusca: Cephalopoda) in the Ria de Vigo (north-west Spain). J. Zool. Zool. Soc. Lond. 211, 515-523. https://doi.org/10.1111/j.1469-7998.1987.tb01549.x.

Guerra, A., Rodríguez-Navarro, A.B., González, A.F., Romanek, C.S., Álvarez-Lloret, P., Pierce, G.J., 2010. Life-history traits of the giant squid Architeuthis dux revealed from stable isotope signatures recorded in beaks. ICES J. Mar. Sci. 67 (7), 1425-1431. https://doi.org/10.1093/icesjms/fsq091.

Guerreiro, M., Phillips, R.A., Cherel, Y., Ceia, F.R., Alvito, P., Rosa, R., Xavier, J.C., 2015 Habitat and trophic ecology of Southern Ocean cephalopods from stable isotope analyses. Mar. Ecol. Prog. Ser. 530, 119-134. https://doi.org/10.3354/meps11266.

Gutt, J., Bertler, N., Bracegirdle, T.J., Buschmann, A., Comiso, J., Hosie, G., et al., 2015 The Southern Ocean ecosystem under multiple climate change stresses - an integrated circumpolar assessment. Glob. Chang. Biol. 21 (4), 1434-1453. https://doi.org/10. $1111 /$ gcb.12794.

Hardin, G., 1960. The competitive exclusion principle. Science 131 (3409), 1292-1297. https://doi.org/10.1126/science.131.3409.1292.

Ho, S.T., Hutmacher, D.W., 2006. A comparison of micro CT with other techniques used in the characterization of scaffolds. Biomaterials 27 (8), 1362-1376.

Hobson, K.A., Welch, H.E., 1992. Determination of trophic relationships within a high Arctic marine food web web using $\delta 13 \mathrm{C}$ and $\delta 15 \mathrm{~N}$ analysis. Mar. Ecol. Prog. Ser. 84 9-18. https://doi.org/10.3354/meps084009.

Hogg, O.T., Huvenne, V.A.I., Griffiths, H.J., Dorschel, B., Linse, K., 2016. Landscape mapping at sub-Antarctic South Georgia provides a protocol for underpinning largescale marine protected areas. Sci. Rep. 6 (33163), 1-15. https://doi.org/10.1038/ srep33163.

MacArthur, R.H., 1958. Population ecology of some warblers of Northeastern Coniferous forests. Ecology 39 (4), 599-619. https://doi.org/10.2307/1931600.

Miserez, A., Schneberk, T., Sun, C., Zok, F.W., Waite, J.H., 2008. The transition from stiff to compliant materials in squid beaks. Science 319 (5871), 1816-1819. https://doi. org/10.1126/science.1154117.

Miserez, A., Youli, L., Waite, J.H., Zok, F.W., 2007. Jumbo squid beaks: inspiration for design of robust organic composites. Acta Biomater. 3 (1), 139-149. https://doi.org/ 10.1016/j.actbio.2006.09.004.

Negri, A., Daneri, G.A., Ceia, F., Vieira, R., Cherel, Y., Coria, N.R., et al., 2016. The cephalopod prey of the Weddell seal, Leptonychotes weddellii, a biological sampler of the Antarctic marine ecosystem. Polar Biol. 39 (3), 561-564. https://doi.org/10.1007/ s00300-015-1794-9.

Nigmatullin, C.M., Nesis, K.N., Arkhipkin, A.I., 2001. A review of the biology of the jumbo squid Dosidicus gigas (Cephalopoda: ommastrephidae). Fish. Res. 54, 9-19.

Pacala, S.W., Roughgarden, J., 1985. Population experiments with the Anolis lizards of st. Maarten and st. Eustatius. Ecology 66 (1), 129-141. https://doi.org/10.2307/ 1941313.

Penicaud, V., Lacoue-Labarthe, T., Bustamante, P., 2017. Metal bioaccumulation and detoxification processes in cephalopods: a review. Environ. Res. 155, 123-133. https://doi.org/10.1016/j.envres.2017.02.003. 
Piatkowski, U., Allcock, A.L., Vecchione, M., 2003. Cephalopod diversity and ecology. Ber. Polar Meeresforsch. 470, 32-38.

Queirós, J., Cherel, Y., Ceia, F.R., Hilário, A., Roberts, J., Xavier, J.C., 2018. Ontogenic changes in habitat and trophic ecology in Antarctic squid Kondakovia longimana derived from stable isotopic analysis on beaks. Polar Biol. 1-13. https://doi.org/10. 1007/s00300-018-2376-4.

R Core Team, 2019. A Language and Environment for Statistical Computing. R Foundation for Statistical Computing, Vienna, Austria.

Rintoul, S.R., Chow, S.L., DeConto, R.M., England, M.H., Fricker, H.A., Masson-Delmotte, V., et al., 2018. Choosing the future of Antarctica. Nature 558 (7709), 233-241. https://doi.org/10.1038/s41586-018-0173-4.

Rodhouse, P.G., Arnbom, T.R., Fedak, M.A., Yeatman, J., Murray, A.W.A., 1992 Cephalopod prey of the southern elephant seal, Mirounga leonina L. Can. J. Zool. 70, 1007-1015.

Rogers, A.D., Yesson, C., Gravestock, P., 2015. Chapter one - a biophysical and economic profile of South Georgia and the South Sandwich Islands as potential large-scale Antarctic protected areas. Adv. Mar. Biol. 70 1-286. https://doi.org/10.1016/bs. amb.2015.06.001.

Schwarz, R., Piatkowski, U., Hoving, H.J.T., 2018. Impact of environmental temperature on the lifespan of octopods. Mar. Ecol. Prog. Ser. 605, 151-164. https://doi.org/10. 3354/meps12749.

Seco, J., Roberts, J., Ceia, F.R., Baeta, A., Ramos, J.A., Paiva, V.H., Xavier, J.C., 2016. Distribution, habitat and trophic ecology of Antarctic squid Kondakovia longimana and Moroteuthis knipovitchi: inferences from predators and stable isotopes. Polar Biol. 39 (1), 167-175. https://doi.org/10.1007/s00300-015-1675-2.

Seco, J., Xavier, J.C., Coelho, J.P., Pereira, B., Tarling, G.A., Pardal, M.A., et al., 2019. Spatial variability in total and organic mercury levels in Antarctic krill Euphausia superba across the Scotia Sea. Environ. Pollut. https://doi.org/10.1016/j.envpol. 2019.01.031.

Seixas, S., Bustamante, P., Pierce, G.J., 2005. Accumulation of mercury in the tissues of the common octopus Octopus vulgaris (L.) in two localities on the Portuguese coast. Sci. Total Environ. 340, 113-122. https://doi.org/10.1016/j.scitotenv.2004.08.012.

Stowasser, G., Atkinson, A., McGill, R.A.R., Phillips, R.A., Collins, M.A., Pond, D.W., 2012. Food web dynamics in the Scotia Sea in summer: a stable isotope study. Deep Sea Res. Part II 59 (60), 208-221. https://doi.org/10.1016/j.dsr2.2011.08.004.

Strugnell, J.M., Allcock, A.L., Watts, P.C., 2017. Closely related octopus species show different spatial genetic structures in response to the Antarctic seascape. Ecol. Evol. 7 (19), 8087-8099.
Trathan, P.N., Collins, M.A., Grant, S.M., Belchier, M., Barnes, D.K.A., Brown, J., Staniland, I.J., 2014. The South Georgia and the South Sandwich Islands MPA: protecting a biodiverse oceanic island chain situated in the flow of the antarctic circumpolar current. Adv. Mar. Biol. 69, 15-78. https://doi.org/10.1016/B978-0-12800214-8.00002-5.

Undheim, E.A.B., Georgieva, D.N., Thoen, H.H., Norman, J.A., Mork, J., Betzel, C., Fry, B.G., 2010. Venom on ice: first insights into Antarctic octopus venoms. Toxicon 56, 897-913. https://doi.org/10.1016/j.toxicon.2010.06.013.

Villanueva, R., Norman, M.D., 2008. Biology of the planktonic stages of benthic octopuses. Oceanogr. Mar. Biol. Annu. Rev. 46, 105-202.

Whitehouse, M.J., Meredith, M.P., Rothery, P., Atkinson, A., Ward, P., Korb, R.E., 2008. Rapid warming of the ocean around South Georgia, Southern Ocean, during the 20th century: forcings, characteristics and implications for lower trophic levels. Deep-Sea Res. Part I Oceanogr. Res. Pap. 55 (10), 1218-1228. https://doi.org/10.1016/j.dsr. 2008.06.002.

Xavier, J.C., Cherel, Y., 2009. Cephalopod Beak Guide for the Southern Ocean. British Antarctic Survey, Cambridge, UK.

Xavier, J.C., Cherel, Y., Allcock, A.L., Rosa, R., Sabirov, R.M., Blicher, M.E., Golikov, A.V., 2018. A review on the biodiversity, distribution and trophic role of cephalopods in the Arctic and Antarctic marine ecosystems under a changing ocean. Mar. Biol. 165 (93), 1-26. https://doi.org/10.1007/s00227-018-3352-9.

Xavier, J.C., Croxall, J.P., Trathan, P.N., Rodhouse, P.G., 2003. Inter-annual variation in the cephalopod component of the diet of the wandering Albatross, Diomedea exulans, breeding at bird island, South Georgia. Mar. Biol. 142, 611-622. https://doi.org/10. 1007/s00227-002-0962-y.

Xavier, J.C., Ferreira, S., Tavares, S., Santos, N., Mieiro, C.L., Trathan, P.N., et al., 2016. The significance of cephalopod beaks in marine ecology studies: can we use beaks for DNA analyses and mercury contamination assessment? Mar. Pollut. Bull. 103 (1-2), 220-226. https://doi.org/10.1016/j.marpolbul.2015.12.016.

Xavier, J.C., Rodhouse, P.G., Purves, M.G., Daw, T.M., Arata, J., Pilling, G.M., 2002 Distribution of cephalopods recorded in the diet of the Patagonian toothfish (Dissostichus eleginoides) around South Georgia. Polar Biol. 25 (5), 323-330. https:// doi.org/10.1007/s00300-001-0343-x.

Yau, C., Allcock, A.L., Daly, H.I., Collins, M.A., 2002. Distribution of Pareledone spp. (octopodidae: eledoninae) around South Georgia. Bull. Mar. Sci. 71 (2), 993-1002.

Zimmer, I., Piatkowski, U., Brey, T., 2007. The trophic link between squid and the emperor penguin Aptenodytes forsteri at Pointe Géologie, Antarctica. Mar. Biol. 152 (5), 1187-1195. https://doi.org/10.1007/s00227-007-0766-1. 